\title{
CRTH2 and D-Type Prostanoid Receptor Antagonists as Novel Therapeutic Agents for Inflammatory Diseases
}

\author{
Rufina Schuligoi Eva Sturm Petra Luschnig Viktoria Konya Sonia Philipose \\ Miriam Sedej Maria Waldhoer Bernhard A. Peskar Akos Heinemann \\ Institute of Experimental and Clinical Pharmacology, Medical University of Graz, Graz, Austria
}

Key Words

CRTH2 - D-type prostanoid receptor - Therapeutic agents

\begin{abstract}
Accumulation of type $2 \mathrm{~T}$ helper (Th2) lymphocytes and eosinophils is a hallmark of bronchial asthma and other allergic diseases, and it is believed that these cells play a crucial pathogenic role in allergic inflammation. Thus, Th2 cells and eosinophils are currently considered a major therapeutic target in allergic diseases and asthma. However, drugs that selectively target the accumulation and activation of Th2 cells and eosinophils in tissues are unavailable so far. Prostaglan$\operatorname{din}(P G) D_{2}$ is a key mediator in various inflammatory diseases including allergy and asthma. It is generated by activated mast cells after allergen exposure and subsequently orchestrates the recruitment of inflammatory cells to the tissue. $\mathrm{PGD}_{2}$ induces the chemotaxis of Th2 cells, basophils and eosinophils, stimulates cytokine release from these cells and prolongs their survival, and might hence indirectly promote IgE production. $\mathrm{PGD}_{2}$ mediates its biologic functions via 2 distinct $G$ protein-coupled receptors, D-type prostanoid receptor (DP), and the chemoattractant receptor-homologous molecule expressed on Th2 cells (CRTH2). DP and CRTH2 receptors are currently being considered as highly promising therapeutic targets for combating allergic diseases and asth-
\end{abstract}

ma. Here, we revisit the roles of $\mathrm{PGD}_{2}$ receptors in the regulation of eosinophil and Th2 cell function and the efforts towards developing candidate compounds for clinical evaluation.

Copyright $\odot 2010$ S. Karger AG, Basel

\section{Introduction}

Atopy is one of the most prevalent diseases in the developed world. The prevalence of allergic rhinitis, conjunctivitis, bronchial asthma and dermatitis among others is as high as $20 \%$ in the populations of Western countries. Atopy is a genetically determined disorder which results in characteristic inflammatory responses to antigens that are innocuous per se. Many forms of atopy such as asthma are associated with a major reduction in quality of life and life expectancy. In addition, some diseases such as intrinsic asthma, aspirin sensitivity, nasal polyposis, adenoid hyperplasia or chronic idiopathic urticaria share several clinical and pathophysiological features of allergy, but with less clear ties to allergens. The pathogenic basis of atopy and related disorders is still only partially understood and no causal therapy, except for specific immunotherapy in selected cases, is available to date. Currently employed symptomatic regimens are

\section{KARGER}

Fax +41613061234

E-Mail karger@karger.ch

www.karger.com
(C) 2010 S. Karger AG, Basel

0031-7012/10/0856-0372\$26.00/0

Accessible online at:

www.karger.com/pha
Univ. Prof. Dr. Akos Heinemann

Institute of Experimental and Clinical Pharmacology, Medical University of Graz Universitätsplatz 4

AT-8010 Graz (Austria)

Tel. +43316380 4508, Fax +43316380 9645, E-Mail akos.heinemann@ medunigraz.at 
frequently ineffective or, like corticosteroids, might have serious side effects $[1,2]$. Therefore, demand persists for additional treatments of allergic diseases, particularly for those patients who need to avoid corticosteroids (e.g. children), and those who are insufficiently treated by standard therapeutic regimens. In the case of bronchial asthma, these patients rely mainly on bronchodilator therapy and are at risk of suffering both from side effects of these drugs and uncontrolled pulmonary inflammation leading to airway remodeling [3]. The discovery of the orphan G protein-coupled receptor GPR44, its expression pattern (basophils, eosinophils and type $2 \mathrm{~T}$ helper, Th2, cells) [4] and its ensuing deorphanization as a receptor for the mast cell-derived mediator prostaglandin $(\mathrm{PG}) \mathrm{D}_{2}[5]$ has fueled additional research in the field. This novel receptor, meanwhile termed 'chemoattractant receptor-homologous molecule expressed on Th 2 cells' (CRTH2), has thus provided an innovative and promising target for antiinflammatory drug development.

\section{Role of $\mathrm{PGD}_{2}$ in Allergic Inflammation}

Like other prostanoids, $\mathrm{PGD}_{2}$ is synthesized by phospholipase $A_{2}$, cyclooxygenase and specific terminal synthases upon activation of cells by different stimuli such as allergens, oxidative stress or cytokines. $\mathrm{PGD}_{2}$ is the major mast cell product that is released during anaphylaxis $[6$, 7] and substantial evidence has accumulated in the last few years that $\mathrm{PGD}_{2}$ might be involved in the initiation and perpetuation of allergic inflammation. However, $\mathrm{PGD}_{2}$ is produced in significant amounts also by dendritic cells, macrophages, eosinophils, Th2 cells and endothelial cells [8-14]. A prominent contribution of $\mathrm{PGD}_{2}$ to the late-phase allergic reaction is, on the one hand, suggested by enhanced eosinophilic lung inflammation and cytokine release in transgenic mice overexpressing PGD synthase [15]. Moreover, $\mathrm{PGD}_{2}$ enhances leukotriene (LT) $\mathrm{C}_{4}$ synthesis by eosinophils during allergic inflammation [16]. Conversely, an inhibitor of hematopoietic PGD synthase attenuates the antigen-induced production of $\mathrm{PGD}_{2}$ and ameliorates airway inflammation in vivo in mice [17]. Interestingly, the biosynthesis of $\mathrm{PGD}_{2}$ increases after the intake of cyclooxygenase inhibitors in aspirin-intolerant patients [18-20]. The resulting imbalance between $\mathrm{PGD}_{2}$ and $\mathrm{PGE}_{2}$ has been suggested to favor the development of asthma and nasal polyposis [21]. On the other hand, $\mathrm{PGD}_{2}$ has been suggested to play a beneficial role in the resolution phase of inflammation by controlling Th1-mediated mechanisms $[22,23]$.

$\mathrm{PGD}_{2}$ Receptors as Therapeutic Targets

\section{Receptors for $\mathrm{PGD}_{2}$}

The biological effects of $\mathrm{PGD}_{2}$ are, in principle, mediated by two distinct $\mathrm{G}$ protein-coupled receptors, D-type prostanoid receptor (DP) and CRTH2. Moreover, at higher concentrations, $\mathrm{PGD}_{2}$ is a ligand for the thromboxane (TX) receptor, which mediates the bronchoconstrictor effect of PGD $2[24,25]$.

\section{Chemoattractant Receptor-Homologous Molecule}

Expressed on Th2 Cells

CRTH2, also known as $\mathrm{DP}_{2}$, GPR44 or CD294, has initially been found on Th2 cells, eosinophils and basophils [4], and mediates their chemotaxis towards $\mathrm{PGD}_{2}$ $[5,26]$. However, the CRTH2 receptor is activated not only by $\mathrm{PGD}_{2}$ but also by several $\mathrm{PGD}_{2}$ metabolites including 13,14-dihydro-15-keto- $\mathrm{PGD}_{2}, \mathrm{PGJ}_{2}, \Delta^{12} \mathrm{PGJ}_{2}$, $\Delta^{12} \mathrm{PGD}_{2}, 9 \alpha, 11 \beta-\mathrm{PGF}_{2}$ and 15 -deoxy-PGJ ${ }_{2}$ [27-30] -, by $\mathrm{PGF}_{2} \alpha$ [30], a thromboxane metabolite, 11-dehydro$\mathrm{TXB}_{2}$ [31], and also by the precursor of all 2-series PG and $\mathrm{TX}, \mathrm{PGH}_{2}$ [32]. In animal models, exogenously administered CRTH2 agonists can induce eosinophil infiltration into the lungs and skin, and aggravate the pathology of allergic responses [33-35]. Moreover, several experimental studies in mice have shown that CRTH2 antagonists can ameliorate allergen-induced cutaneous, pulmonary and upper respiratory inflammation [36-41]. In humans, sequence variants of the gene encoding CRTH2 are associated with asthma and allergic phenotypes [42]. In addition, recent data suggest that CRTH2 is also expressed on monocytes [43] and macrophages, and mediates their migration induced by $\mathrm{PGD}_{2}$ and endotoxin $[8,44]$. Strikingly, $\mathrm{PGD}_{2}$ levels in bronchoalveolar lavage fluid of patients with chronic obstructive pulmonary disease correlate inversely with lung function [45]. Therefore, using CRTH2 antagonists is currently being considered as a highly promising approach to the treatment of allergic diseases and asthma. Interestingly, a CRTH2 antagonist is currently being evaluated in phase II trials in patients with chronic obstructive pulmonary disease (clinical trial registration No. NCT00690482, NCT00766415).

$\mathrm{CRTH} 2$ signals through $\mathrm{G} \alpha_{\mathrm{i}}$ proteins, leading to inhibition of cAMP formation and increases in intracellular $\mathrm{Ca}^{2+}$ [5]. In eosinophils, however, we observed that CRTH2 stimulation leads to pertussis-toxin-insensitive activation of phosphatidylinositol 3-kinase (PI3K), phospholipase C, p38 mitogen-activated protein kinase (MAPK) and mitogen-activated protein kinase/extracellular signal-regulated kinase kinase [46]. These pathways mediate eosinophil shape change, actin polymerization

Pharmacology 2010;85:372-382 
and CD11b upregulation $[26,46]$. The migration and survival of Th2 cells in response to $\mathrm{PGD}_{2}$-induced stimulation of CRTH2 depend on PI3K, while $\mathrm{PGD}_{2}$-evoked cytokine release involves PI3K, calcineurin and nuclear factor of activated $\mathrm{T}$ cells [47]. On the other hand, preactivation of p38 MAPK and glycogen synthase kinase- $3 \beta$ restrain the CRTH2-mediated migration of eosinophils and the cytokine section of Th2 cells, respectively $[47,48]$. A recent study revealed that, unexpectedly, $\mathrm{CRTH} 2$ is not phosphorylated upon agonist stimulation, a mechanism by which the activity of most $\mathrm{G}$ protein-coupled receptors is typically regulated. Instead, the $\mathrm{C}$ terminus of $\mathrm{CRTH} 2$ inhibits $\mathrm{G} \alpha_{\mathrm{i}}$ signaling, which may compensate for the $\mathrm{ab}$ sence of the classical phosphorylation-dependent signal attenuation [49].

\section{D-Type Prostanoid Receptor}

$\mathrm{DP}$, also referred to as $\mathrm{DP}_{1}$, is expressed more widely than CRTH2, including platelets, several types of leukocytes, the vasculature, the central nervous system, retina, nasal mucosa, lungs and intestine [5, 50-54]. Activation of the DP receptor results in cutaneous and pulmonary venous vasodilatation, arterial hypotension, mucin secretion, inhibition of platelet aggregation and lowering of intraocular pressure [54-60]. DP has been described to play both antiinflammatory and proinflammatory roles: on the one hand, DP activation inhibits the function of neutrophils, basophils, dendritic cells, Langerhans cells, Th1 cells and natural killer cells [43, 61-67]. In vivo, inhalation of a selective DP agonist suppresses asthma in a murine model by downmodulation of lung dendritic cell function and induction of regulatory T cells [68]. In addition, $\mathrm{PGD}_{2}$ but not $\mathrm{CRTH} 2$ agonists inhibit the scratching response of mice with atopic dermatitis [69]. Stimulation of DP enhances the barrier function of endothelial cells [70] and confers protection to neurons [71]. On the other hand, $\mathrm{PGD}_{2}$ and DP receptors contribute to astrogliosis and demyelination in the twitcher mouse model [72]. $\mathrm{PGD}_{2}$ synergizes with tumor necrosis factor via DP receptors to promote the production of monocyte chemotactic protein-1 and interleukin (IL)-8 in monocytic cells [73]. In vivo, a DP antagonist blocks antigen-induced rhinitis, conjunctivitis and eosinophil infiltration into the lung of the guinea pig $[74,75]$ and experimental asthma in sheep [76]. DP-deficient mice exhibit reduced pulmonary inflammation in response to allergens [77]. The DP receptor is expressed on bronchiole epithelial cells in antigen-challenged mice [77], as well as nasal epithelial goblet cells in normal human volunteers [52], suggesting that DP might stimulate mucus secretion in allergy. More- over, an association of polymorphisms of the DP promoter and gene with asthma has been detected in humans [78]. These findings hence point to a proinflammatory role of DP, but are difficult to reconcile with the known functional responses to DP receptor activation.

Despite the fact that it has comparable avidity for $\mathrm{PGD}_{2}$, the DP receptor shows little similarity with the CRTH2 receptor. In addition to $\mathrm{PGD}_{2}, \Delta^{12} \mathrm{PGD}_{2}, \mathrm{PGJ}_{2}$ and $\mathrm{PGH}_{2}$ are also potent DP agonists, while other metabolites of $\mathrm{PGD}_{2}$ such as 13,14-dihydro-15-keto- $\mathrm{PGD}_{2}$ and 15-deoxy-PG $]_{2}$ are selective for CRTH2 $[5,27,29$, 32, 79]. DP receptor activation leads to $G \alpha_{s}$-mediated increases in intracellular cAMP although an agonistevoked $\mathrm{Ca}^{2+}$ flux has also been observed in heterologous expression systems $[50,80]$. The effects exerted by $\mathrm{PGD}_{2}$ on dendritic cells are associated with the phosphorylation of cAMP response element-binding protein, but do not parallel with a deactivation of nuclear factor- $\kappa \mathrm{B}$ and MAPK pathways [43]. So far, further downstream signaling pathways subsequent to DP activation have received very little attention. Interestingly, $\mathrm{PGD}_{2}$ stimulation of fibroblast repair in an in vitro collagen contraction assay is mediated by $\mathrm{DP}$ and $\mathrm{Ca}^{2+}$-independent protein kinase $\mathrm{C}$, but it is independent of cAMP and protein kinase A [81].

\section{Regulation of Eosinophil Responses by $\mathrm{PGD}_{2}$}

Eosinophils play important roles in late-phase reactions by releasing bronchoconstrictor mediators such as $\mathrm{LTC}_{4}$ and other chemoattractants which cause further influx of inflammatory cells into the tissue [82]. Like Th2 cells, eosinophils produce and release proinflammatory cytokines and growth factors including the immunoregulatory type 2 cytokines IL-4, IL-5, IL-10 and IL-13 [83]. Mucosal damage in chronic asthma is associated with cytotoxic and proinflammatory mediators that are released by activated eosinophils. Consequently, eosinophils also play a role in airway remodeling and angiogenesis in chronically inflamed tissue [84]. Importantly, it was shown that asthmatic patients who receive treatment based on eosinophil counts in sputum have significantly fewer severe asthma exacerbations than patients treated according to standard management therapy [85]. Moreover, animal studies also demonstrated that genetically modified mice lacking eosinophils are protected against allergen-induced lung injury and asthma [86, 87]. Therefore, eosinophils are currently considered a major therapeutic target in allergic diseases and asthma [88], but they 
might also play pathogenic roles in several other diseases such as eosinophilic esophagitis [89], colitis ulcerosa [90], hypereosinophilic syndrome [91] or renal disease [92].

In many eosinophilic inflammatory diseases, eosinophilia has been attributed to reduced eosinophil apoptosis [93]. The Th2 cytokine IL-5 augments eosinophil recruitment and survival in experimental models of allergic inflammation. However, the limited clinical efficacy of antibodies against IL-5 in ameliorating asthma symptoms [94] suggests that additional mediators are also involved, such as granulocyte-macrophage colonystimulating factor or a plethora of chemoattractants that can stimulate the locomotion of eosinophils. In particular, these chemoattractants comprise the ligands of the chemokine receptor CCR3 [95] including eotaxin-1, -2 and -3 , RANTES and the monocyte chemotactic peptides monocyte chemotactic protein-3 and -4 . Moreover, activated complement factors such as C5a, and lipid mediators such as $\mathrm{LTB}_{4}$ [96], platelet activation factor [97] and 5-oxo-6,8,11,14-eicosatetraenoic acid (5-oxoETE) are also potent chemoattractants for eosinophils [98-100].

As mentioned above, $\mathrm{PGD}_{2}$ and several of its metabolites are potent chemoattractants for eosinophils and this effect mainly relies on CRTH2 activation $[5,28,32]$. Moreover, we observed that $\mathrm{PGD}_{2}$ and its metabolites are capable of stimulating the release of mature eosinophils from bone marrow $[28,101]$. However, $\mathrm{PGD}_{2}$ not only stimulates eosinophil trafficking but also activates eosinophils with respect to the respiratory burst and release of eosinophil cationic protein, and delays their apoptosis $[28,53]$. While most $\mathrm{PGD}_{2}$ effects in eosinophils are mediated by CRTH2, we could demonstrate that DP receptors are also involved in eosinophil chemotaxis, respiratory burst and mobilization from bone marrow $[101,102]$. In contrast, the antiapoptotic effect of $\mathrm{PGD}_{2}$ in eosinophils is solely mediated by DP receptors [53]. In addition to directly stimulating eosinophil migration, we also demonstrated that $\mathrm{PGD}_{2}$ very efficiently primes eosinophils for other chemoattractants like eotaxin, 5-oxo-ETE or C5a $[28,48]$. The priming effect of $\mathrm{PGD}_{2}$ is exclusively mediated via CRTH2 receptors. In contrast, eosinophil migration towards $\mathrm{PGD}_{2}$ is strikingly decreased by other chemoattractants such as eotaxin or 5-oxo-ETE, and PI3K as well as p38 MAPK are involved in these inhibitory effects. Conversely, the priming effect of $\mathrm{PGD}_{2}$ is not reversed by inhibition of PI3K, p38 MAPK or peroxisome proliferator-activated receptor- $\gamma$, which has been described to mediate the priming effect of the $\mathrm{PGD}_{2}$ metabolite 15-deoxy- $\Delta^{12,14}-\mathrm{PGJ}_{2}$ [103].

$\mathrm{PGD}_{2}$ Receptors as Therapeutic Targets
Interestingly, available data also suggest that $\mathrm{PGD}_{2}$ might inhibit eosinophil degranulation, as investigated by the $\mathrm{C} 5 \mathrm{a}$-induced upregulation of the granule-associated marker CD63 on eosinophils and the release of eosinophil peroxidase $[32,48,101]$. This effect is likewise mediated exclusively by CRTH2 receptors. From these studies we inferred that there is a hierarchy among eosinophil chemoattractants: $\mathrm{PGD}_{2}$ might be an initial chemoattractant since it maintains its potency also in whole blood [48] and augments the responsiveness of eosinophils to other chemoattractants, but restrains eosinophil degranulation. In contrast, eotaxin seems to be an end point chemoattractant since it has a reduced efficacy in blood, is capable of downmodulating eosinophil responsiveness to other chemoattractants and stimulates eosinophil degranulation $[48,104]$.

CRTH2 expression levels are likely to be elevated in eosinophils from patients with allergic diseases, as suggested by observations in atopic dermatitis [105].

\section{Role of $\mathrm{PGD}_{2}$ Receptors in Regulation of Th2 Lymphocyte Function}

Ligation of the $\mathrm{T}$ cell receptor by the antigen-major histocompatibility complex class II induces the clonal expansion of naïve Th lymphocytes and their differentiation into at least four subtypes of effector cells: Th1, Th2, Th17 and regulatory $\mathrm{T}\left(\mathrm{T}_{\mathrm{reg}}\right)$ cells. Th cells can be divided into two subsets, Th1 and Th2, based on their cytokine expression profile. Th1 lymphocytes are characterized by the production of interferon (IFN)- $\gamma$ and IL-2, whereas Th2 lymphocytes produce IL-4, IL-5, IL- 6, IL-10 and IL-13 [106]. The cytokines produced by the Th1 lymphocytes, in particular IFN- $\gamma$, activate macrophages and are essentially responsible for cell-mediated immunity against intracellular pathogens [106]. In contrast, Th2 cytokines are responsible for humoral immune responses as well as the growth and differentiation of mast cells and eosinophils, and are involved in antibody-mediated responses to extracellular parasites [107]. Recently identified Th17 cells mainly express IL-17 and are crucial in certain autoimmune diseases [108]. $\mathrm{T}_{\text {reg }}$ cells are known to suppress various immune responses including autoimmune responsiveness [109]. An imbalance in the relative proportion and function of Th cell populations, as determined by the complex interaction of the genetic background with environmental factors such as exposure to certain infectious agents, has been implicated in the development of abnormal immune re- 
sponses and the onset of autoimmune and allergic conditions [110].

Asthma and allergy are inflammatory diseases caused by dysregulation of immune responses in the mucosa or the skin, and it is believed that exaggerated Th2-driven responses play a crucial pathogenic role. Several studies have documented increased numbers of activated CD4positive T cells showing a Th2 profile in the lungs of asthmatic subjects [111-113]. Thus, CD4-positive T cells producing Th 2 cytokines play a prominent role in the lungs, particularly because IL- 4 and IL-13 enhance IgE production, IL-4, IL-9 and IL-10 enhance mast cell growth, IL-5 enhances eosinophil accumulation, and IL-9 and IL-13 directly enhance mucus hypersecretion and airway hyperreactivity $[114,115]$. Activated Th2 cells are the main cells expressing CD40 ligand (CD40L), and binding of CD40L to CD40 molecules on B cells and dendritic cells promotes their IgE production and antigen-presenting capability, respectively [116]. Correspondingly, clinically useful drugs such as corticosteroids potently suppress cytokine expression in Th2 cells $[113,117]$. Although it is clear that Th2-driven immune responses critically regulate the development of allergy and asthma, the underlying causes for Th2 overactivity are still unclear and, to date, no specific therapeutic regimens are available to restrain Th2 overactivity.

A large number of cell surface molecules have been reported to be differentially expressed between Th1 and Th2 cells. For example, the chemokine receptors CXCR3 and CCR5 are selectively expressed on in-vitro-derived Th1 lymphocytes, whereas CCR4, CCR 8 and CCR 3 are expressed on Th2 lymphocytes [118-121]. Most importantly, CRTH2 has been identified as a receptor that is selectively expressed on Th2 cells [5] and it has been proposed that CRTH2 is the most selective marker for human Th2 cells in peripheral blood [122]. In contrast, the DP receptor is expressed in both Th1 and Th2 subsets, and reinforces an inhibitory effect on cytokine production, e.g. IFN- $\gamma$ and IL-4, respectively [65]. As mentioned above, CRTH2 mediates the migration of Th2 cells towards $\mathrm{PGD}_{2}$ [5]. Furthermore, activation of the CRTH2 receptor induces the production of proinflammatory cytokines in Th2 cells $[65,123]$, upregulates the expression of CD40L on Th2 cells [65], and delays their apoptosis [124]. Interestingly, Th2 cells can themselves produce $\mathrm{PGD}_{2}$, which may constitute an autocrine mechanism to recruit further Th2 cells to the inflamed tissue [11]. In vitro studies have revealed that $\mathrm{CRTH} 2$ expression increases during Th2 polarization [125] and the number of CRTH2-positive cells in peripheral blood is elevated in patients with atopic dermatitis or HIV infection [122, 126]. These findings suggest that CRTH2 might be a highly promising therapeutic target as the blockade of CRTH2 by means of small-molecule antagonists is likely to attenuate Th2 activity with respect to their accumulation at sites of inflammation, cytokine release and survival in tissue.

\section{Further Inflammatory Cells Expressing CRTH2}

Basophils were among the first cells that were shown to express CRTH2 and to migrate towards $\mathrm{PGD}_{2}[5,127]$. Moreover, CRTH2 activation was found to enhance basophil expression of the adhesion molecule CD11b and histamine release, while activation of the DP receptor was found to have opposing effects in basophils [62, 128]. CRTH2 is also detectable in human monocytes and murine macrophages and mediates their migration towards $\mathrm{PGD}_{2}$ and endotoxin, respectively $[8,43]$. Similarly, $\mathrm{PGD}_{2}$ is chemotactic for murine bone marrow-derived mast cells and this response is ablated by a CRTH2 antagonist [129]. Correspondingly, elevated numbers of CRTH2positive macrophages and mast cells are present in nasal mucosa of allergic patients [44].

\section{Antagonists of $\mathrm{PGD}_{2}$ Receptors as Novel Therapeutic Agents}

\section{CRTH2 Receptor Antagonists}

Our laboratory and others have simultaneously discovered that the cyclooxygenase inhibitor indomethacin is a potent CRTH2 agonist $[46,130]$, which has thus provided a useful pharmacophore for small-molecule antagonists to CRTH2 [131-134]. Consecutively, it was shown that ramatroban, formerly used as a TX receptor antagonist, was also a potent CRTH2 antagonist in cell lines transfected with CRTH2 and in human eosinophils [31, 131]. Mathiesen et al. described three novel ramatroban analogs that differ chemically from ramatroban by either (i) a single additional methyl group, or (ii) an acetic acid instead of a propionic acid side chain, or (iii) a combination of both [133]. Each of the three compounds acted as a potent CRTH2 antagonist, yet the nature of their antagonism differed markedly, either decreasing the affinity of $\mathrm{PGD}_{2}$ to $\mathrm{CRTH} 2$, or depressing the ligand-binding capacity causing functional insurmountability. One of these compounds (now referred to as TM30089 or Cay10471) proved to be one of the most potent CRTH2 
antagonists described so far. Currently, three chemical classes of CRTH2 antagonists have been reported: (i) indole-acetic acids and ramatroban derivates [127, 135139]; (ii) phenylacetic acids [140-142], and (iii) tetrahydroquinolines [143, 144]. Although several phase II trials have been conducted with CRTH2 antagonists, only one study has been presented so far: when compared with placebo, oral treatment with a CRTH2 antagonist for 28 days of moderate persistent asthmatics free of inhaled steroids showed significant beneficial effects with respect to forced expiratory volume, peak flow, circulating IgE levels, nighttime asthma symptoms and quality of life [145].

\section{DP Receptor Antagonists}

The hydantoin derivative, BWA868c, was the first selective DP antagonist available [25]. Subsequently, a class of bicycloheptane-derivative DP antagonists, including S-5751, has been developed that block the actions of $\mathrm{PGD}_{2}$ in experimental models of inflammation $[74,75]$. In addition to being a starting point for the synthesis of CRTH2 antagonists, indomethacin was also a useful pharmacophore for a number of DP antagonists including laropiprant [146-148]. Although recent phase II studies in asthmatics and patients with allergic rhinitis failed to confirm the promising results obtained from animal models [149], DP antagonisms might be useful in other forms of inflammatory disease. In addition, laropiprant is currently being marketed in combination with niacin as Tredaptive ${ }^{\circledR}$ to prevent niacin-induced flush that is partially mediated by $\mathrm{PGD}_{2}[150]$.

\section{Bivalent CRTH2/DP Receptor Antagonists}

Considering the multiple roles that DP and CRTH2 receptors play in allergic disease, a hybrid antagonist may exert clinically relevant, beneficial effects that are not achieved when just one $\mathrm{PGD}_{2}$ receptor is blocked. For in- stance, DP antagonism would prevent IL-12 generation by dendritic cells and the ensuing polarization of Th2 cells, while CRTH2 antagonism could prevent the recruitment of eosinophils, basophils and Th2 cells to inflammatory sites [151]. Dual CRTH2/DP antagonists derived from phenylacetic acid have recently been presented [152].

\section{Conclusion}

For a long time, $\mathrm{PGD}_{2}$ has been disregarded as a byproduct of mast cells with unclear biological relevance. The discovery of its novel receptor, CRTH2, has fueled extensive research into the biology and pharmacology of $\mathrm{PGD}_{2}$ and has attracted enormous attention from the pharmaceutical industry. Currently, $\mathrm{PGD}_{2}$ receptor antagonists are being developed for the treatment of allergic diseases and asthma, but they might also be useful in other diseases that involve eosinophils, or even in chronic obstructive pulmonary disease. Small-molecule antagonists of CRTH2 and DP have already been demonstrated to be efficacious in a variety of animal models and their clinical usefulness in human disease will be unveiled in the near future.

\section{Acknowledgments}

V.K., S.P. and M.S. were funded by the PhD Program Molecular Medicine of the Medical University of Graz. This study was supported by the Jubiläumsfonds of the Austrian National Bank (grant No. 11967 and 13487), the Austrian Science Fund FWF (grant No. P19424-B05 and P22521-B18) and the Franz Lanyar Foundation (grant No. 315, 316 and 343). A.H. has received research support and consultancy fees from AstraZeneca and Almirall.

\section{References}

1 Dahl R: Systemic side effects of inhaled corticosteroids in patients with asthma. Respir Med 2006;100:1307-1317.

2 McDonough AK, Curtis JR, Saag KG: The epidemiology of glucocorticoid-associated adverse events. Curr Opin Rheumatol 2008; 20:131-137.

3 Wraight JM, Smith AD, Cowan JO, Flannery EM, Herbison GP, Taylor DR: Adverse effects of short-acting beta-agonists: potential impact when anti-inflammatory therapy is inadequate. Respirology 2004;9:215-221.

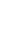

Nagata K, Hirai H, Tanaka K, Ogawa K, Aso T, Sugamura K, Nakamura M, Takano S: CRTH2, an orphan receptor of $\mathrm{T}$ helper 2 cells, is expressed on basophils and eosinophils and responds to mast cell-derived factor(s). FEBS Lett 1999;459:195-199.

5 Hirai H, Tanaka K, Yoshie O, Ogawa K, Kenmotsu K, Takamori Y, Ichimasa M, Sugamura K, Nakamura M, Takano S, Nagata K: Prostaglandin $\mathrm{D}_{2}$ selectively induces chemotaxis in Thelper type 2 cells, eosinophils, and basophils via seven-transmembrane receptor CRTH2. J Exp Med 2001;193:255-261.

\footnotetext{
-6 Anhut H, Peskar BA, Bernauer W: Release of 15-keto-13,14-dihydro-thromboxane $\mathrm{B}_{2}$ and prostaglandin $\mathrm{D}_{2}$ during anaphylaxis as measured by radioimmunoassay. Naunyn Schmiedebergs Arch Pharmacol 1978;305: 247-252.

7 Schleimer RP, Fox CC, Naclerio RM, Plaut M, Creticos PS, Togias AG, Warner JA, Kagey-Sobotka A, Lichtenstein LM: Role of human basophils and mast cells in the pathogenesis of allergic diseases. J Allergy Clin Immunol 1985;76:369-374.
} 
8 Tajima T, Murata T, Aritake K, Urade Y, Hirai H, Nakamura M, Ozaki H, Hori M: Lipopolysaccharide induces macrophage migration via prostaglandin $\mathrm{D}_{2}$ and prostaglandin $\mathrm{E}_{2}$. J Pharmacol Exp Ther 2008;326:493-501.

-9 Söderström M, Wigren J, Surapureddi S, Glass CK, Hammarström S: Novel prostaglandin $\mathrm{D}_{2}$-derived activators of peroxisome proliferator-activated receptor-gamma are formed in macrophage cell cultures. Biochim Biophys Acta 2003;1631:35-41.

- 10 Urade Y, Ujihara M, Horiguchi Y, Ikai K, Hayaishi O: The major source of endogenous prostaglandin $\mathrm{D}_{2}$ production is likely antigen-presenting cells: localization of glutathione-requiring prostaglandin D synthetase in histiocytes, dendritic, and Kupffer cells in various rat tissues. J Immunol 1989;143: 2982-2989.

-11 Vinall SL, Townsend ER, Pettipher R: A paracrine role for chemoattractant receptorhomologous molecule expressed on T helper type 2 cells (CRTH2) in mediating chemotactic activation of CRTH2+CD4+ T helper type 2 lymphocytes. Immunology 2007;121: 577-584.

-12 Hyo S, Kawata R, Kadoyama K, Eguchi N, Kubota T, Takenaka H, Urade Y: Expression of prostaglandin $\mathrm{D}_{2}$ synthase in activated eosinophils in nasal polyps. Arch Otolaryngol Head Neck Surg 2007;133:693-700.

$\checkmark 13$ Camacho M, Lopez-Belmonte J, Vila L: Rate of vasoconstrictor prostanoids released by endothelial cells depends on cyclooxygenase-2 expression and prostaglandin I synthase activity. Circ Res 1998;83:353-365.

-14 Soler M, Camacho M, Escudero JR, Iniguez MA, Vila L: Human vascular smooth muscle cells but not endothelial cells express prostaglandin E synthase. Circ Res 2000;87:504507.

-15 Fujitani Y, Kanaoka Y, Aritake K, Uodome N, Okazaki-Hatake K, Urade Y: Pronounced eosinophilic lung inflammation and Th2 cytokine release in human lipocalin-type prostaglandin D synthase transgenic mice. J Immunol 2002;168:443-449.

- 16 Mesquita-Santos FP, Vieira-de-Abreu A Calheiros AS, Figueiredo IH, Castro-FariaNeto HC, Weller PF, Bozza PT, Diaz BL, Bandeira-Melo C: Cutting edge: prostaglandin $\mathrm{D}_{2}$ enhances leukotriene $\mathrm{C}_{4}$ synthesis by eosinophils during allergic inflammation: synergistic in vivo role of endogenous eotaxin. J Immunol 2006;176:1326-1330.

- 17 Aritake K, Kado Y, Inoue T, Miyano M, Urade Y: Structural and functional characterization of HQL-79, an orally active, selective inhibitor for human hematopoietic prostaglandin D synthase. J Biol Chem 2006;281: 15277-15286.

-18 Szczeklik A, Sladek K, Dworski R, Nizankowska E, Soja J, Sheller J, Oates J: Bronchial aspirin challenge causes specific eicosanoid response in aspirin-sensitive asthmatics. Am J Respir Crit Care Med 1996; 154:1608-1614.
19 O’Sullivan S, Dahlén B, Dahlén SE, Kumlin $\mathrm{M}$ : Increased urinary excretion of the prostaglandin $\mathrm{D}_{2}$ metabolite $9 \alpha, 11 \beta$-prostaglandin $\mathrm{F}_{2}$ after aspirin challenge supports mast cell activation in aspirin-induced airway obstruction. J Allergy Clin Immunol 1996;98: 421-432.

20 Higashi N, Mita H, Ono E, Fukutomi Y, Yamaguchi H, Kajiwara K, Tanimoto H, Sekiya K, Akiyama K, Taniguchi M: Profile of eicosanoid generation in aspirin-intolerant asthma and anaphylaxis assessed by new biomarkers. J Allergy Clin Immunol 2010, Epub ahead of print.

21 Pierzchalska M, Szabo Z, Sanak M, Soja J, Szczeklik A: Deficient prostaglandin $\mathrm{E}_{2}$ production by bronchial fibroblasts of asthmatic patients, with special reference to aspirininduced asthma. J Allergy Clin Immunol 2003;111:1041-1048.

22 Ajuebor MN, Singh A, Wallace JL: Cyclooxygenase-2-derived prostaglandin $\mathrm{D}_{2}$ is an early anti-inflammatory signal in experimental colitis. Am J Physiol Gastrointest Liver Physiol 2000;279:G238-G244.

-23 Trivedi SG, Newson J, Rajakariar R, Jacques TS, Hannon R, Kanaoka Y, Eguchi N, Colville-Nash P, Gilroy DW: Essential role for hematopoietic prostaglandin $\mathrm{D}_{2}$ synthase in the control of delayed-type hypersensitivity. Proc Natl Acad Sci USA 2006; 103:5179-5184.

24 Coleman RA, Sheldrick RL: Prostanoid-induced contraction of human bronchial smooth muscle is mediated by TP receptors. Br J Pharmacol 1989;96:688-692.

25 Giles H, Leff P, Bolofo ML, Kelly MG, Robertson AD: The classification of prostaglandin DP receptors in platelets and vasculature using BW A868C, a novel, selective and potent competitive antagonist. Br J Pharmacol 1989;96:291-300.

26 Monneret G, Gravel S, Diamond M, Rokach J, Powell WS: Prostaglandin $\mathrm{D}_{2}$ is a potent chemoattractant for human eosinophils that acts via a novel DP receptor. Blood 2001;98: 1942-1948.

27 Monneret G, Li H, Vasilescu J, Rokach J, Powell WS: 15 -deoxy- $\Delta^{12,14}$-prostaglandins $\mathrm{D}_{2}$ and $\mathrm{J}_{2}$ are potent activators of human eosinophils. J Immunol 2002;168:3563-3569.

28 Heinemann A, Schuligoi R, Sabroe I, Hartnell A, Peskar BA: $\Delta^{12}$-prostaglandin $\mathrm{J}_{2}$, a plasma metabolite of prostaglandin $\mathrm{D}_{2}$ causes eosinophil mobilization from the bone marrow and primes eosinophils for chemotaxis. J Immunol 2003;170:47524758.

29 Gazi L, Gyles S, Rose J, Lees S, Allan C, Xue L, Jassal R, Speight G, Gamble V, Pettipher R $\Delta^{12}$-prostaglandin $\mathrm{D}_{2}$ is a potent and selective CRTH2 receptor agonist and causes activation of human eosinophils and Th2 lymphocytes. Prostaglandins Other Lipid Mediat 2005;75:153-167.

-30 Sandig H, Andrew D, Barnes AA, Sabroe I, Pease J: $9 \alpha, 11 \beta-\mathrm{PGF}_{2}$ and its stereoisomer
$\mathrm{PGF}_{2} \alpha$ are novel agonists of the chemoattractant receptor, CRTH2. FEBS Lett 2006; 580:373-379.

-31 Böhm E, Sturm GJ, Weiglhofer I, Sandig H, Shichijo M, McNamee A, Pease JE, Kollroser M, Peskar BA, Heinemann A: 11-dehydrothromboxane $\mathrm{B}_{2}$, a stable thromboxane metabolite, is a full agonist of chemoattractant receptor-homologous molecule expressed on Th2 cells (CRTH2) in human eosinophils and basophils. J Biol Chem 2004;279:7663-7670.

-32 Schuligoi R, Sedej M, Waldhoer M, Vukoja A, Sturm EM, Lippe IT, Peskar BA, Heinemann A: Prostaglandin $\mathrm{H}_{2}$ induces the migration of human eosinophils through the chemoattractant receptor homologous molecule of Th2 cells, CRTH2. J Leukoc Biol 2009;85:136-145.

>33 Almishri W, Cossette C, Rokach J, Martin JG, Hamid Q, Powell W: Effects of prostaglandin $\mathrm{D}_{2}, 15$-deoxy- $\Delta^{12,14}$-prostaglandin $\mathrm{J}_{2}$, and selective $\mathrm{DP}_{1}$ and $\mathrm{DP}_{2}$ receptor agonists on pulmonary infiltration of eosinophils in brown Norway rats. J Pharmacol Exp Ther 2005;313:64-69.

34 Shiraishi Y, Asano K, Nakajima T, Oguma T, Suzuki Y, Shiomi T, Sayama K, Niimi K, Wakaki M, Kagyo J, Ikeda E, Hirai H, Yamaguchi K, Ishizaka A: Prostaglandin $\mathrm{D}_{2}$-induced eosinophilic airway inflammation is mediated by CRTH2 receptor. J Pharmacol Exp Ther 2005;312:954-960.

35 Spik I, Brenuchon C, Angeli V, Staumont D, Fleury S, Capron M, Trottein F, Dombrowicz D: Activation of the prostaglandin $\mathrm{D}_{2}$ receptor $\mathrm{DP}_{2} / \mathrm{CRTH} 2$ increases allergic inflammation in mouse. J Immunol 2005; 174:37033708.

36 Uller L, Mathiesen JM, Alenmyr L, Korsgren M, Ulven T, Högberg T, Andersson G, Persson CG, Kostenis E: Antagonism of the prostaglandin $\mathrm{D}_{2}$ receptor $\mathrm{CRTH} 2$ attenuates asthma pathology in mouse eosinophilic airway inflammation. Respir Res 2007;8:16.

37 Lukacs NW, Berlin AA, Franz-Bacon K, Sasik R, Sprague LJ, Ly TW, Hardiman G, Boehme SA, Bacon KB: CRTH2 antagonism significantly ameliorates airway hyperreactivity and downregulates inflammation-induced genes in a mouse model of airway inflammation. Am J Physiol Lung Cell Mol Physiol 2008;295:L767-L779.

38 Oiwa M, Satoh T, Watanabe M, Niwa H, Hirai H, Nakamura M, Yokozeki H: CRTH2dependent, STAT6-independent induction of cedar pollen dermatitis. Clin Exp Allergy 2008;38:1357-1366.

39 Shiraishi Y, Asano K, Niimi K, Fukunaga K, Wakaki M, Kagyo J, Takihara T, Ueda S, Nakajima T, Oguma T, Suzuki Y, Shiomi T, Sayama K, Kagawa S, Ikeda E, Hirai H, Nagata K, Nakamura M, Miyasho T, Ishizaka A: Cyclooxygenase-2/prostaglandin $\mathrm{D}_{2}$ / CRTH2 pathway mediates double-stranded RNA-induced enhancement of allergic airway inflammation. J Immunol 2008; 180 : 541-549. 
40 Nomiya R, Okano M, Fujiwara T, Maeda M, Kimura Y, Kino K, Yokoyama M, Hirai H, Nagata K, Hara T, Nishizaki K, Nakamura M: CRTH2 plays an essential role in the pathophysiology of Cry j 1-induced pollinosis in mice. J Immunol 2008;180:56805688.

-41 Boehme SA, Chen EP, Franz-Bacon K, Sasik R, Sprague LJ, Ly TW, Hardiman G, Bacon KB: Antagonism of CRTH2 ameliorates chronic epicutaneous sensitization-induced inflammation by multiple mechanisms. Int Immunol 2009;21:1-17.

42 Cameron L, Depner M, Kormann M, Klopp N, Illig T, von Mutius E, Kabesch M: Genetic variation in CRTh2 influences development of allergic phenotypes. Allergy 2009;64: 1478-1485.

43 Gosset P, Bureau F, Angeli V, Pichavant M, Faveeuw C, Tonnel AB, Trottein F: Prostaglandin $\mathrm{D}_{2}$ affects the maturation of human monocyte-derived dendritic cells: consequence on the polarization of naive Th cells. J Immunol 2003;170:4943-4952.

-44 Shirasaki H, Kikuchi M, Kanaizumi E, Himi T: Accumulation of CRTH2-positive leukocytes in human allergic nasal mucosa. Ann Allergy Asthma Immunol 2009;102:110115.

-45 Csanky E, Ruhl R, Scholtz B, Vasko A, Takacs L, Hempel WM: Lipid metabolite levels of prostaglandin $\mathrm{D}_{2}$ and eicosapentaenoic acid recovered from bronchoalveolar lavage fluid correlate with lung function of chronic obstructive pulmonary disease patients and controls. Electrophoresis 2009;30:12281234.

-46 Stubbs VE, Schratl P, Hartnell A, Williams TJ, Peskar BA, Heinemann A, Sabroe I: Indomethacin causes prostaglandin $\mathrm{D}_{2}$-like and eotaxin-like selective responses in eosinophils and basophils. J Biol Chem 2002;277: 26012-26020.

47 Xue L, Gyles SL, Barrow A, Pettipher R: Inhibition of PI3K and calcineurin suppresses chemoattractant receptor-homologous molecule expressed on Th2 cells (CRTH2)-dependent responses of Th2 lymphocytes to prostaglandin $\mathrm{D}_{2}$. Biochem Pharmacol 2007; 73:843-853.

-48 Schratl P, Sturm EM, Royer JF, Sturm GJ, Lippe IT, Peskar BA, Heinemann A: Hierarchy of eosinophil chemoattractants: role of p38 mitogen-activated protein kinase. Eur J Immunol 2006;36:2401-2409.

-49 Schröder R, Merten N, Mathiesen JM, Martini L, Kruljac-Letunic A, Krop F, Blaukat A, Fang Y, Tran E, Ulven T, Drewke C, Whistler J, Pardo L, Gomeza J, Kostenis E: The C-terminal tail of CRTH2 is a key molecular determinant that constrains $\mathrm{G} \alpha_{\mathrm{i}}$ and downstream signaling cascade activation. J Biol Chem 2009;284:1324-1336.

50 Boie Y, Sawyer N, Slipetz DM, Metters KM, Abramovitz M: Molecular cloning and characterization of the human prostanoid DP receptor. J Biol Chem 1995;270:18910-18916.
Gerashchenko D, Beuckmann CT, Kanaoka Y, Eguchi N, Gordon WC, Urade Y, Bazan NG, Hayaishi O: Dominant expression of rat prostanoid DP receptor $\mathrm{mRNA}$ in leptomeninges, inner segments of photoreceptor cells, iris epithelium, and ciliary processes. J Neurochem 1998;71:937-945.

52 Nantel F, Fong C, Lamontagne S, Wright DH, Giaid A, Desrosiers M, Metters KM, O'Neill GP, Gervais FG: Expression of prostaglandin D synthase and the prostaglandin $\mathrm{D}_{2}$ receptors DP and CRTH2 in human nasal mucosa. Prostaglandins Other Lipid Mediat 2004;73:87-101.

53 Gervais FG, Cruz RP, Chateauneuf A, Gale S, Sawyer N, Nantel F, Metters KM, O’Neill GP: Selective modulation of chemokinesis, degranulation, and apoptosis in eosinophils through the $\mathrm{PGD}_{2}$ receptors CRTH2 and DP J Allergy Clin Immunol 2001;108:982-988.

54 Wright DH, Ford-Hutchinson AW, Chadee K, Metters KM: The human prostanoid DP receptor stimulates mucin secretion in LS174T cells. Br J Pharmacol 2000;131:15371545.

55 Whittle BJ, Moncada S, Mullane K, Vane JR: Platelet and cardiovascular activity of the hydantoin BW245C, a potent prostaglandin analogue. Prostaglandins 1983;25:205-223.

56 Gray SJ, Giles H, Posner J: The effect of a prostaglandin DP receptor partial agonist (192C86) on platelet aggregation and the cardiovascular system in healthy volunteers. $\mathrm{Br}$ J Clin Pharmacol 1992;34:344-351.

57 Walch L, Labat C, Gascard JP, de Montpreville V, Brink C, Norel X: Prostanoid receptors involved in the relaxation of human pulmonary vessels. Br J Pharmacol 1999;126: 859-866.

58 Woodward DF, Spada CS, Hawley SB, Williams LS, Protzman CE, Nieves AL: Further studies on ocular responses to DP receptor stimulation. Eur J Pharmacol 1993;230:327333.

59 Moreland RB, Nehra A, Kim NN, Min KS, Albadawi H, Watkins MT, Goldstein I, Traish AM: Expression of functional prostaglandin D (DP) receptors in human corpus cavernosum smooth muscle. Int J Impot Res 2002; 14:446-452.

60 van Hecken A, Depré M, de Lepeleire I, Thach C, Oeyen M, van Effen J, Laethem T, Mazina K, Crumley T, Wenning L, Gottesdiener KM, Deutsch P, Clement P, Lai E, de Hoon JN: The effect of MK-0524, a prostaglandin $\mathrm{D}_{2}$ receptor antagonist, on prostaglandin $\mathrm{D}_{2}$-induced nasal airway obstruction in healthy volunteers. Eur J Clin Pharmacol 2007;63:135-141.

-61 Wheeldon A, Vardey CJ: Characterization of the inhibitory prostanoid receptors on human neutrophils. Br J Pharmacol 1993;108: 1051-1054.

62 Yoshimura-Uchiyama C, Iikura M, Yamaguchi M, Nagase H, Ishii A, Matsushima K, Yamamoto K, Shichijo M, Bacon KB, Hirai K: Differential modulation of human basophil functions through prostaglandin $\mathrm{D}_{2}$ receptors DP and chemoattractant receptor-homologous molecule expressed on Th2 cells/ $\mathrm{DP}_{2}$. Clin Exp Allergy 2004;34:1283-1290.

63 Hammad H, de Heer HJ, Soullie T, Hoogsteden HC, Trottein F, Lambrecht BN: Prostaglandin $\mathrm{D}_{2}$ inhibits airway dendritic cell migration and function in steady-state conditions by selective activation of the $\mathrm{D}$ prostanoid receptor 1. J Immunol 2003;171:39363940.

-64 Angeli V, Faveeuw C, Roye O, Fontaine J, Teissier E, Capron A, Wolowczuk I, Capron $\mathrm{M}$, Trottein F: Role of the parasite-derived prostaglandin $\mathrm{D}_{2}$ in the inhibition of epidermal Langerhans cell migration during schistosomiasis infection. J Exp Med 2001;193: 1135-1147.

65 Tanaka K, Hirai H, Takano S, Nakamura M, Nagata K: Effects of prostaglandin $\mathrm{D}_{2}$ on helper $\mathrm{T}$ cell functions. Biochem Biophys Res Commun 2004;316:1009-1014.

66 Chen Y, Perussia B, Campbell KS: Prostaglandin $\mathrm{D}_{2}$ suppresses human NK cell function via signaling through $\mathrm{D}$ prostanoid receptor. J Immunol 2007;179:2766-2773.

67 Torres D, Paget C, Fontaine J, Mallevaey T, Matsuoka T, Maruyama T, Narumiya S, Capron M, Gosset P, Faveeuw C, Trottein F: Prostaglandin $\mathrm{D}_{2}$ inhibits the production of IFN-gamma by invariant NK T cells: consequences in the control of B16 melanoma. J Immunol 2008; 180:783-792.

-68 Hammad H, Kool M, Soullie T, Narumiya S, Trottein F, Hoogsteden HC, Lambrecht BN: Activation of the $\mathrm{D}$ prostanoid 1 receptor suppresses asthma by modulation of lung dendritic cell function and induction of regulatory T cells. J Exp Med 2007;204:357-367.

-69 Arai I, Takano N, Hashimoto Y, Futaki N, Sugimoto M, Takahashi N, Inoue T, Nakaike $\mathrm{S}$ : Prostanoid $\mathrm{DP}_{1}$ receptor agonist inhibits the pruritic activity in NC/Nga mice with atopic dermatitis. Eur J Pharmacol 2004;505: 229-235.

-70 Murata T, Lin MI, Aritake K, Matsumoto S, Narumiya S, Ozaki H, Urade Y, Hori M, Sessa WC: Role of prostaglandin $\mathrm{D}_{2}$ receptor DP as a suppressor of tumor hyperpermeability and angiogenesis in vivo. Proc Natl Acad Sci USA 2008;105:20009-20014.

71 Liang X, Wu L, Hand T, Andreasson K: Prostaglandin $\mathrm{D}_{2}$ mediates neuronal protection via the $\mathrm{DP}_{1}$ receptor. J Neurochem 2005;92: 477-486.

72 Mohri I, Taniike M, Taniguchi H, Kanekiyo T, Aritake K, Inui T, Fukumoto N, Eguchi N, Kushi A, Sasai H, Kanaoka Y, Ozono K, Narumiya S, Suzuki K, Urade Y: Prostaglandin $\mathrm{D}_{2}$-mediated microglia/astrocyte interaction enhances astrogliosis and demyelination in twitcher. J Neurosci 2006;26:43834393.

73 Hirano Y, Shichijo M, Deguchi M, Nagira M, Suzuki N, Nishitani Y, Hattori M, Arimura A: Synergistic effect of $\mathrm{PGD}_{2}$ via prostanoid DP receptor on TNF-alpha-induced produc- 
tion of MCP-1 and IL-8 in human monocytic THP-1 cells. Eur J Pharmacol 2007;560: $81-88$.

-74 Arimura A, Yasui K, Kishino J, Asanuma F, Hasegawa H, Kakudo S, Ohtani M, Arita H: Prevention of allergic inflammation by a novel prostaglandin receptor antagonist, S-5751. J Pharmacol Exp Ther 2001;298:411419.

-75 Yasui K, Asanuma F, Hirano Y, Shichijo M, Deguchi M, Arimura A: Contribution of prostaglandin $\mathrm{D}_{2}$ via prostanoid $\mathrm{DP}$ receptor to nasal hyperresponsiveness in guinea pigs repeatedly exposed to antigen. Eur J Pharmacol 2008;578:286-291

-76 Shichijo M, Arimura A, Hirano Y, Yasui K, Suzuki N, Deguchi M, Abraham WM: A prostaglandin $\mathrm{D}_{2}$ receptor antagonist modifies experimental asthma in sheep. Clin Exp Allergy 2009;39:1404-1414.

-77 Matsuoka T, Hirata M, Tanaka H, Takahashi Y, Murata T, Kabashima K, Sugimoto Y, Kobayashi T, Ushikubi F, Aze Y, Eguchi N, Urade Y, Yoshida N, Kimura K, Mizoguchi A, Honda Y, Nagai H, Narumiya S: Prostaglandin $\mathrm{D}_{2}$ as a mediator of allergic asthma. Science 2000;287:2013-2017.

-78 Zhu G, Vestbø J, Lenney W, Silverman M, Whyte M, Helms P, Anderson WH, Pillai SG: Association of PTGDR gene polymorphisms with asthma in two Caucasian populations. Genes Immun 2007;8:398-403.

-79 Schuligoi R, Schmidt R, Geisslinger G, Kollroser M, Peskar BA, Heinemann A: $\mathrm{PGD}_{2}$ metabolism in plasma: kinetics and relationship with bioactivity on $\mathrm{DP}_{1}$ and CRTH2 receptors. Biochem Pharmacol 2007;74:107117.

80 Hirata M, Kakizuka A, Aizawa M, Ushikubi F, Narumiya S: Molecular characterization of a mouse prostaglandin $\mathrm{D}$ receptor and functional expression of the cloned gene. Proc Natl Acad Sci USA 1994;91:1119211196.

-81 Kohyama T, Wyatt TA, Liu X, Wen FQ, Kobayashi T, Fang Q, Kim HJ, Rennard SI: $\mathrm{PGD}_{2}$ modulates fibroblast-mediated native collagen gel contraction. Am J Respir Cell Mol Biol 2002;27:375-381.

-82 O’Byrne PM: Leukotrienes in the pathogenesis of asthma. Chest 1997;111:27S-34S.

83 Woerly G, Roger N, Loiseau S, Capron M: Expression of Th1 and Th2 immunoregulatory cytokines by human eosinophils. Int Arch Allergy Immunol 1999;118:95-97.

84 Aceves SS, Broide DH: Airway fibrosis and angiogenesis due to eosinophil trafficking in chronic asthma. Curr Mol Med 2008;8:350358.

-85 Green RH, Brightling CE, McKenna S, Hargadon B, Parker D, Bradding P, Wardlaw AJ, Pavord ID: Asthma exacerbations and sputum eosinophil counts: a randomised controlled trial. Lancet 2002;360:1715-1721.

86 Humbles AA, Lloyd CM, McMillan SJ, Friend DS, Xanthou G, McKenna EE, Ghiran S, Gerard NP, Yu C, Orkin SH, Gerard C: A critical role for eosinophils in allergic airways remodeling. Science 2004;305:17761779 .

87 Lee JJ, Dimina D, Macias MP, Ochkur SI, McGarry MP, O’Neill KR, Protheroe C, Pero $\mathrm{R}$, Nguyen T, Cormier SA, Lenkiewicz E, Colbert D, Rinaldi L, Ackerman SJ, Irvin CG, Lee NA: Defining a link with asthma in mice congenitally deficient in eosinophils. Science 2004;305:1773-1776.

88 Foster PS, Rosenberg HF, Asquith KL, Kumar RK: Targeting eosinophils in asthma. Curr Mol Med 2008;8:585-390.

89 Straumann A, Simon HU: Eosinophilic esophagitis: escalating epidemiology? J Allergy Clin Immunol 2005;115:418-419.

90 Wedemeyer J, Vosskuhl K: Role of gastrointestinal eosinophils in inflammatory bowel disease and intestinal tumours. Best Pract Res Clin Gastroenterol 2008;22:537-549.

91 Simon D, Simon HU: Eosinophilic disorders. J Allergy Clin Immunol 2007;119:12911300.

92 Fukui M, Tanaka M, Hamaguchi M, Senmaru T, Sakabe K, Shiraishi E, Harusato I, Yamazaki M, Hasegawa G, Nakamura N: Eosinophil count is positively correlated with albumin excretion rate in men with type 2 diabetes. Clin J Am Soc Nephrol 2009;4: 1761-1765.

93 Simon HU: Molecules involved in the regulation of eosinophil apoptosis. Chem Immunol Allergy 2006;91:49-58.

94 Leckie MJ: Anti-interleukin-5 monoclonal antibodies: preclinical and clinical evidence in asthma models. Am J Respir Med 2003;2. 245-259.

95 Garcia-Zepeda EA, Combadiere C, Rothenberg ME, Sarafi MN, Lavigne F, Hamid Q, Murphy PM, Luster AD: Human monocyte chemoattractant protein (MCP)-4 is a novel CC chemokine with activities on monocytes, eosinophils, and basophils induced in allergic and nonallergic inflammation that signals through the CC chemokine receptors (CCR)2 and -3. J Immunol 1996;157:5613-5626.

96 Nagy L, Lee TH, Goetzl EJ, Pickett WC, Kay $\mathrm{AB}$ : Complement receptor enhancement and chemotaxis of human neutrophils and eosinophils by leukotrienes and other lipoxygenase products. Clin Exp Immunol 1982;47: 541-547.

97 Wardlaw AJ, Moqbel R, Cromwell O, Kay AB: Platelet-activating factor: a potent chemotactic and chemokinetic factor for human eosinophils. J Clin Invest 1986;78:17011706

$\checkmark 98$ Powell WS, Chung D, Gravel S: 5-oxo6,8,11,14-eicosatetraenoic acid is a potent stimulator of human eosinophil migration. J Immunol 1995;154:4123-4132.

99 Sturm GJ, Schuligoi R, Sturm EM, Royer JF, Lang-Loidolt D, Stammberger H, Amann R, Peskar BA, Heinemann A: 5-oxo-6,8,11,14eicosatetraenoic acid is a potent chemoattractant for human basophils. J Allergy Clin Immunol 2005;116:1014-1019.
100 Sturm EM, Schratl P, Schuligoi R, Konya V, Sturm GJ, Lippe IT, Peskar BA, Heinemann A: Prostaglandin $\mathrm{E}_{2}$ inhibits eosinophil trafficking through E-prostanoid 2 receptors. J Immunol 2008;181:72737283.

101 Schratl P, Royer JF, Kostenis E, Ulven T, Sturm EM, Waldhoer M, Hoefler G, Schuligoi R, Lippe IT, Peskar BA, Heinemann A: The role of the prostaglandin $\mathrm{D}_{2}$ receptor, DP, in eosinophil trafficking. J Immunol 2007;179:4792-4799.

102 Royer JF, Schratl P, Lorenz S, Kostenis E, Ulven T, Schuligoi R, Peskar BA, Heinemann A: A novel antagonist of CRTH2 blocks eosinophil release from bone marrow, chemotaxis and respiratory burst. Allergy 2007;62:1401-1409.

103 Kobayashi Y, Ueki S, Mahemuti G, Chiba T, Oyamada H, Saito N, Kanda A, Kayaba H, Chihara J: Physiological levels of 15-deoxy$\Delta^{12,14}$-prostaglandin $\mathrm{J}_{2}$ prime eotaxin-induced chemotaxis on human eosinophils through peroxisome proliferator-activated receptor-gamma ligation. J Immunol 2005; 175:5744-5750

104 Fujisawa T, Kato Y, Nagase H, Atsuta J, Terada A, Iguchi K, Kamiya H, Morita Y, Kitaura M, Kawasaki H, Yoshie O, Hirai K: Chemokines induce eosinophil degranulation through CCR-3. J Allergy Clin Immunol 2000; 106:507-513.

105 Yahara H, Satoh T, Miyagishi C, Yokozeki $\mathrm{H}$ : Increased expression of CRTH2 on eosinophils in allergic skin diseases. J Eur Acad Dermatol Venereol 2010;24:75-76.

106 Annunziato F, Galli G, Cosmi L, Romagnani P, Manetti R, Maggi E, Romagnani S: Molecules associated with human Th1 or Th2 cells. Eur Cytokine Netw 1998;9:1216.

107 Romagnani S: Cytokines and chemoattractants in allergic inflammation. Mol Immunol 2002;38:881-885.

108 Peck A, Mellins ED: Precarious balance: Th17 cells in host defense. Infect Immun 2010;78:32-38.

109 Robinson DS: Regulatory T cells and asthma. Clin Exp Allergy 2009;39:1314-1323.

110 Wills-Karp M, Santeliz J, Karp CL: The germless theory of allergic disease: revisiting the hygiene hypothesis. Nat Rev Immunol 2001;1:69-75

- 111 Robinson DS, Hamid Q, Ying S, Tsicopoulos A, Barkans J, Bentley AM, Corrigan C, Durham SR, Kay AB: Predominant Th2like bronchoalveolar T lymphocyte population in atopic asthma. N Engl J Med 1992; 326:298-304.

112 Robinson D, Hamid Q, Bentley A, Ying S, Kay AB, Durham SR: Activation of CD4+ T cells, increased Th2-type cytokine mRNA expression, and eosinophil recruitment in bronchoalveolar lavage after allergen inhalation challenge in patients with atopic asthma. J Allergy Clin Immunol 1993;92: 313-324. 
-113 Corrigan CJ, Hamid Q, North J, Barkans J, Moqbel R, Durham S, Gemou-Engesaeth V, Kay AB: Peripheral blood CD4 but not CD8 $\mathrm{T}$ lymphocytes in patients with exacerbation of asthma transcribe and translate messenger RNA encoding cytokines which prolong eosinophil survival in the context of a Th2-type pattern: effect of glucocorticoid therapy. Am J Respir Cell Mol Biol 1995; 12:567-578.

114 Umetsu DT, DeKruyff RH: Th1 and Th2 CD4+ cells in human allergic diseases. J Allergy Clin Immunol 1997;100:1-6.

1115 Wills-Karp M, Luyimbazi J, Xu X, Schofield B, Neben TY, Karp CL, Donaldson DD: Interleukin-13: central mediator of allergic asthma. Science 1998;282:2258-2261.

-116 Banchereau J, Bazan F, Blanchard D, Brière F, Galizzi JP, van Kooten C, Liu YJ, Rousset F, Saeland S: The CD40 antigen and its ligand. Annu Rev Immunol 1994;12:881-922.

- 117 Umland SP, Nahrebne DK, Razac S, Beavis A, Pennline KJ, Egan RW, Billah MM: The inhibitory effects of topically active glucocorticoids on IL-4, IL-5, and interferongamma production by cultured primary CD4+ T cells. J Allergy Clin Immunol 1997; 100:511-519.

- 118 Colantonio L, Recalde H, Sinigaglia F, D’Ambrosio D: Modulation of chemokine receptor expression and chemotactic responsiveness during differentiation of human naive T cells into Th1 or Th2 cells. Eur J Immunol 2002;32:1264-1273.

-119 Bonecchi R, Bianchi G, Bordignon PP, D’Ambrosio D, Lang R, Borsatti A, Sozzani S, Allavena P, Gray PA, Mantovani A, Sinigaglia F: Differential expression of chemokine receptors and chemotactic responsiveness of type $1 \mathrm{~T}$ helper cells (Th1s) and Th2s. J Exp Med 1998;187:129-134.

120 Sallusto F, Lenig D, Mackay CR, Lanzavecchia A: Flexible programs of chemokine receptor expression on human polarized $\mathrm{T}$ helper 1 and 2 lymphocytes. J Exp Med 1998; 187:875-883.

-121 Syrbe U, Siveke J, Hamann A: Th1/Th2 subsets: distinct differences in homing and chemokine receptor expression? Springer Semin Immunopathol 1999;21:263-285.

122 Cosmi L, Annunziato F, Galli MIG, Maggi RME, Nagata K, Romagnani S: CRTH2 is the most reliable marker for the detection of circulating human type 2 Th and type 2 T cytotoxic cells in health and disease. Eur J Immunol 2000;30:2972-2979.

$\checkmark 123$ Xue L, Gyles SL, Wettey FR, Gazi L, Townsend E, Hunter MG, Pettipher R: Prostaglandin $\mathrm{D}_{2}$ causes preferential induction of proinflammatory Th2 cytokine production through an action on chemoattractant receptor-like molecule expressed on Th2 cells. J Immunol 2005;175:65316536.

124 Xue L, Barrow A, Pettipher R: Novel function of CRTH2 in preventing apoptosis of human Th2 cells through activation of the phosphatidylinositol 3-kinase pathway. J Immunol 2009;182:7580-7586.

125 de Fanis U, Mori F, Kurnat RJ, Lee WK, Bova M, Adkinson NF, Casolaro V: GATA3 up-regulation associated with surface expression of CD294/CRTH2: a unique feature of human Th cells. Blood 2007;109: 4343-4350.

126 Iwasaki M, Nagata K, Takano S, Takahashi K, Ishii N, Ikezawa Z: Association of a newtype prostaglandin $\mathrm{D}_{2}$ receptor $\mathrm{CRTH} 2$ with circulating $T$ helper 2 cells in patients with atopic dermatitis. J Invest Dermatol 2002;119:609-616.

127 Royer JF, Schratl P, Carrillo JJ, Jupp R, Barker J, Weyman-Jones C, Beri R, Sargent C, Schmidt JA, Lang-Loidolt D, Heinemann A: A novel antagonist of prostaglandin $\mathrm{D}_{2}$ blocks the locomotion of eosinophils and basophils. Eur J Clin Invest 2008; 38:663-671.

128 Monneret G, Boumiza R, Gravel S, Cossette C, Bienvenu J, Rokach J, Powell WS: Effects of prostaglandin $\mathrm{D}_{2}$ and 5-lipoxygenase products on the expression of CD203c and CD11b by basophils. J Pharmacol Exp Ther 2005;312:627-634.

129 Boehme SA, Franz-Bacon K, Chen EP, Ly TW, Kawakami Y, Bacon KB: Murine bone marrow-derived mast cells express chemoattractant receptor-homologous molecule expressed on $\mathrm{T}$ helper class 2 cells (CRTH2). Int Immunol 2009;21:621-632.

130 Hirai H, Tanaka K, Takano S, Ichimasa M, Nakamura M, Nagata K: Cutting edge: agonistic effect of indomethacin on a prostaglandin $\mathrm{D}_{2}$ receptor, CRTH2. J Immunol 2002;168:981-985.

131 Sugimoto H, Shichijo M, Iino T, Manabe Y, Watanabe A, Shimazaki M, Gantner F, Bacon KB: An orally bioavailable small molecule antagonist of $\mathrm{CRTH} 2$, ramatroban (BAY u3405), inhibits prostaglandin $\mathrm{D}_{2}$ induced eosinophil migration in vitro. Pharmacol Exp Ther 2003;305:347-352.

132 Mathiesen JM, Ulven T, Martini L, Gerlach LO, Heinemann A, Kostenis E: Identification of indole derivatives exclusively interfering with a $G$ protein-independent signaling pathway of the prostaglandin $\mathrm{D}_{2}$ receptor CRTH2. Mol Pharmacol 2005;68:393-402.

133 Mathiesen JM, Christopoulos A, Ulven T, Royer J, Campillo M, Heinemann A, Pardo L, Kostenis E: On the mechanism of interaction of potent, surmountable and insurmountable antagonists with the prostaglandin $\mathrm{D}_{2}$ receptor CRTH2. Mol Pharmacol 2006;69:1441-1453.

134 Liu F, Gonzalo JA, Manning S, O’Connell LE, Fedyk ER, Burke KE, Elder AM, Pulido JC, Cao W, Tayber O, Qiu Y, Ghosh S, Ocain TD, Hodge MR, Suzuki-Yagawa Y: Pharmacological characterization of guinea pig chemoattractant receptor-homologous molecule expressed on Th2 cells (CRTH2). Prostaglandins Other Lipid Mediat 2005; 76:133-147.
135 Armer RE, Ashton MR, Boyd EA, Brennan CJ, Brookfield FA, Gazi L, Gyles SL, Hay PA, Hunter MG, Middlemiss D, Whittaker M, Xue L, Pettipher R: Indole-3-acetic acid antagonists of the prostaglandin $\mathrm{D}_{2}$ receptor CRTH2. J Med Chem 2005;48:6174-6177.

136 Ulven T, Kostenis E: Minor structural modifications convert the dual TP/CRTH2 antagonist ramatroban into a highly selective and potent CRTH 2 antagonist. J Med Chem 2005;48:897-900.

137 Birkinshaw TN, Teague SJ, Beech C, Bonnert RV, Hill S, Patel A, Reakes S, Sanganee H, Dougall IG, Phillips TT, Salter S, Schmidt J, Arrowsmith EC, Carrillo J, Bell FM, Paine SW, Weaver R: Discovery of potent $\mathrm{CRTH} 2\left(\mathrm{DP}_{2}\right)$ receptor antagonists. Bioorg Med Chem Lett 2006;16:4287-4290.

138 Stearns BA, Baccei C, Bain G, Broadhead A, Clark RC, Coate H, Evans JF, Fagan P, Hutchinson JH, King C, Lee C, Lorrain DS, Prasit P, Prodanovich P, Santini A, Scott JM, Stock NS, Truong YP: Novel tricyclic antagonists of the prostaglandin $\mathrm{D}_{2}$ receptor $\mathrm{DP}_{2}$ with efficacy in a murine model of allergic rhinitis. Bioorg Med Chem Lett 2009;19:4647-4651.

139 Sandham DA, Adcock C, Bala K, Barker L, Brown Z, Dubois G, Budd D, Cox B, Fairhurst RA, Furegati M, Leblanc C, Manini J, Profit R, Reilly J, Stringer R, Schmidt A, Turner KL, Watson SJ, Willis J, Williams G, Wilson C: 7-azaindole-3-acetic acid derivatives: potent and selective $\mathrm{CRTH} 2$ receptor antagonists. Bioorg Med Chem Lett 2009;19:4794-4798.

140 Bauer PH, Cheng JB, Gladue RP, Li B, Neote KS, Zhang J: Methods for the identification of compounds useful for the treatment of disease states mediated by prostaglandin $\mathrm{D}_{2}$. Eur Patent No EP1170594 A2. 2002.

141 Bonnert RV, Patel A, Thom S: Phenoxyacetic acid derivatives. Int Patent No WO2005/018529A3. 2005.

142 Sandham DA, Aldcroft C, Baettig U, Barker L, Beer D, Bhalay G, Brown Z, Dubois G, Budd D, Bidlake L, Campbell E, Cox B, Everatt B, Harrison D, Leblanc CJ, Manini J, Profit R, Stringer R, Thompson KS, Turner KL, Tweed MF, Walker C, Watson SJ, Whitebread S, Willis J, Williams G, Wilson C: 2-cycloalkyl phenoxyacetic acid CRTH2 receptor antagonists. Bioorg Med Chem Lett 2007;17:4347-4350.

143 Awad MMA, Bazin M, Feru F, Goldstein SW, Kuhn CF: Tetrahydroquinoline derivatives as CRTH2 antagonists. Int Patent No WO2004/035543. 2004

144 Mimura H, Ikemura T, Kotera O, Sawada M, Tashiro S, Fuse E, Ueno K, Manabe H, Ohshima E, Karasawa A, Miyaji H: Inhibitory effect of the 4-aminotetrahydroquinoline derivatives, selective chemoattractant receptor-homologous molecule expressed on Thelper 2 cell antagonists, on eosinophil migration induced by prostaglandin $\mathrm{D}_{2}$. J Pharmacol Exp Ther 2005;314:244-251. 
145 Barnes NB, Pavord IP, Cuchalin AC, et al: A randomised, double-blind, placebo-controlled study of the CRTH2 antagonist OC000459 on moderate persistent asthma (abstract 3267). ERS Annual Congress, Vienna, 2009.

146 Torisu K, Kobayashi K, Iwahashi M, Egashira H, Nakai Y, Okada Y, Nanbu F, Ohuchida S, Nakai H, Toda M: Development of a prostaglandin $\mathrm{D}_{2}$ receptor antagonist: discovery of a new chemical lead. Eur J Med Chem 2005;40:505-519.
147 Sturino CF, O’Neill G, Lachance N, Boyd M, Berthelette C, Labelle M, Li L, Roy B, Scheigetz J, Tsou N, Aubin Y, Bateman KP, Chauret N, Day SH, Lévesque JF, Seto C, Silva JH, Trimble LA, Carrière MC, Denis D, Greig G, Kargman S, Lamontagne S, Mathieu MC, Sawyer N, Slipetz D, Abraham WM, Jones T, McAuliffe M, Piechuta $\mathrm{H}$ Nicoll-Griffith DA, Wang Z, Zamboni R, Young RN, Metters KM: Discovery of a potent and selective prostaglandin $\mathrm{D}_{2}$ receptor antagonist. J Med Chem 2007;50:794806.

-148 Beaulieu C, Guay D, Wang Z, Leblanc Y, Roy P, Dufresne C, Zamboni R, Berthelette C, Day S, Tsou N, Denis D, Greig G, Mathieu MC, O’Neill G: Identification of prostaglandin $\mathrm{D}_{2}$ receptor antagonists based on a tetrahydropyridoindole scaffold. Bioorg Med Chem Lett 2008;18:2696-2700.
149 Philip G, van Adelsberg J, Loeys T, Liu N, Wong P, Lai E, Dass SB, Reiss TF: Clinical studies of the $\mathrm{DP}_{1}$ antagonist laropiprant in asthma and allergic rhinitis. J Allergy Clin Immunol 2009;124:942-948.e9.

150 Kamanna VS, Ganji SH, Kashyap ML: The mechanism and mitigation of niacin-induced flushing. Int J Clin Pract 2009;63: 1369-1377.

151 Jones RL, Giembycz MA, Woodward DF: Prostanoid receptor antagonists: development strategies and therapeutic applications. Br J Pharmacol 2009;158:104-145.

152 Liu J, Fu Z, Wang Y, Schmitt M, Huang A, Marshall D, Tonn G, Seitz L, Sullivan T, Lucy Tang H, Collins T, Medina J: Discovery and optimization of CRTH2 and DP dual antagonists. Bioorg Med Chem Lett 2009;19:6419-6423. 